Received: 26-01-2021

(Date-Month-Year)
Revised: 05-04-2021

(Date-Month-Year)
Published: 30-04-2021

(Date-Month-Year)

\title{
STATISTICAL LITERACY OF SECONDARY SCHOOL STUDENTS IN SOLVING CONTEXTUAL PROBLEMS TAKING INTO ACCOUNT THE INITIAL STATISTICAL ABILITY
}

\author{
Erlyanna Nur Risqi ${ }^{1}$, Rini Setianingsih ${ }^{2}$ \\ ${ }^{1}$ Mathematics/ Mathematics Education, State University of Surabaya \\ ${ }^{2}$ Mathematics/ Mathematics Education, State University of Surabaya \\ 1erlyanna.17030174026@mhs.unesa.ac.id \\ ${ }^{2}$ rinisetianingsih@unesa.ac.id
}

\begin{abstract}
Statistical literacy is strongly needed in the 21 st century in reading data information, thinking critically and making decisions. The purpose of this study is to describe the statistical literacy abilities of high school students in solving contextual problems taking into account their initial statistical abilities, with the following indicators, Tier 1 (reading \& explaining data), Tier 2 (analyzing, interpreting, interpreting critically, and making conclusions), Tier 3 (presenting data and predicting something). This research is a qualitative in nature, using statistical ability test, statistical literacy test, and interview guidelines to collect data. The subjects of this study consist of three female students of grade XII Senior High School, with high, medium and low initial statistical ability categories. The results of this study revealed that (1) The student with high initial statistical abilities can meet the indicators of Tier 1, Tier 2, Tier 3, so that she can be categorized at level 5 to 6 (criticalmathematics critical), (2) The student with medium ability can fulfil the Tier 1 indicator not fulfil the indicators in Tier 2 and Tier 3, so that it can be categorized at level 3 to 5 (Consistent noncriticalCritical), and (3) The students with low abilities can fulfill the indicators of Tier 1 not fulfil the indicators in Tier 2 and Tier 3, so that it can be categorized at level 1 to 3 (Idiosyncratic-Consistent Noncritical). Therefore, it is important for students and teachers to know statistical literacy skills in order to increase their understanding and ability to understand information in making decisions regarding daily problems.
\end{abstract}

Keywords: Statistical Literacy; Contextual Problem; Initial Statistics Ability.

\begin{abstract}
Abstrak: Literasi statistik sangat dibutuhkan di abad 21 dalam membaca informasi data, berpikir kritis dan mengambil keputusan. Tujuan dari penelitian ini adalah untuk mendeskripsikan kemampuan literasi statistik siswa SMA dalam menyelesaikan masalah kontekstual ditinjau dari kemampuan awal statistika dengan indikator Tier 1 (membaca data \& menjelaskan), Tier2 (menganalisis, menafsirkan, menginterpretasi secara kritis dan membuat kesimpulan), Tier3 (menyajikan data dan memprediksi suatu hal). Penelitian ini merupakan penelitian deskriptif kualitatif dengan menggunakan tes kemampuan statistika, tes literasi statistik, dan pedoman wawancara untuk mengumpulkan data. Subjek yang dipilih dalam penelitian ini yaitu tiga siswa perempuan kelas XII SMA IPA dengan kategori kemampuan awal statistika tinggi, sedang dan rendah. Hasil dari penelitian ini menunjukkan bahwa (1) Siswa dengan kemampuan awal statistika tinggi dapat memenuhi indikator Tier 1, Tier 2, Tier 3 sehingga dapat dikategorikan berada pada level 5 sampai 6 (Critical-Mathematics Critical), (2) Siswa dengan kemampuan sedang dapat memenuhi indikator Tier 1 belum memenuhi indikator pada Tier 2 dan Tier 3 sehingga dapat dikategorikan berada pada level 3 sampai 5 (Consistent NoncriticalCritical), dan (3) Siswa dengan kemampuan rendah dapat memenuhi indikator Tier 1 belum memenuhi indikator pada Tier 2 dan Tier 3 sehingga dapat dikategorikan berada pada level 1 sampai 3 (Idiosyncratic-Consistent Noncritical). Oleh karena itu, penting bagi siswa dan guru untuk mengetahui kemampuan literasi statistik agar dapat meningkatkan pemahaman dan kemampuan memahami informasi dalam mengambil keputusan berkenaan dengan masalah sehari-hari.
\end{abstract}

Kata Kunci: Literasi Statistik; Masalah Kontekstual; Kemampuan Awal Statistik.

Pi: Mathematics Education Journal 


\section{Introduction}

In the 21st century, communication, collaboration, critical thinking and problem-solving skills are strongly needed (van Laar et al., 2020). This ability can be pursued through literacy of numeracy. This is in line with Mardliyah's (2018) research results which reveal that literacy of numeracy has a very important role in improving critical thinking skills. Numeracy literacy is the knowledge and ability to apply numbers and basic mathematical symbols to solve problems and then analyze them to make prediction and decisions (Education \& Jakarta, 2017). Numeracy literacy skills are used in everyday life, for example when reading information on crime cases, the number of people suffering Covid-19, planning holidays or choosing public universities. Information in newspapers, television, online media and social media is usually presented in numbers and graphics.

To realize literacy and numeracy skills in making decisions, someone needs the ability to understand information data, which is called statistical literacy. This is in line with the results of Abdullah's research (2017) that statistical material is needed to train students' ability to think critically. Statistical literacy is important for productive societies in the revolutionary era (Yuniawatika, 2018).

Statistical literacy according to Gal (2002) is the ability to interpret, critically evaluate, and convey statistical information and messages. Literacy focuses on inductive reasoning and arguments in making debatable decisions. In addition, according to Yuniawatika (2018) statistical literacy is described as the ability to understand, interpret, evaluate, and communicate statistical data through various media. Therefore, it can be concluded that statistical literacy is an individual's ability to read data, analyze, interpret, interpret, make conclusions and make predictions using statistical terminology.

Statistical literacy can be applied on learning statistics material. Statistics is an important component of the mathematics curriculum. This is reinforced by NCTM (1989) that statistical knowledge is needed by students in order to become smart consumers who can think critically and make wise decisions. GAISE (Guidiness an Assessment for Statistics Education) states that every school must teach statistical literacy to every student (Carver, 2016). This is parallel to what are stated in the curriculum in Indonesia for high school level, which cover the following materials: (1) analyzing data, means, medians and modes, as well as data distribution to draw conclusions, make decisions, and make predictions; and (2) present and solve related problems. with data distribution, mean, median, mode, and data distribution to draw conclusions, make decisions, and make predictions. (Permendikbud, 2016).

One method of testing students' statistical literacy skills is by providing contextual problems, that are problems related to everyday life, such as information in newspapers, television, radio and social media. This is just the same as the statement of Sharma (2017), that students' statistical literacy must be able to interpret the results of media news, and be able to ask questions about them. Eka's research (2020) states that a contextual approach will improve students' mathematical literacy skills. In addition, according to Gal (2019), meaningful and important contexts should be considered when teaching statistical literacy.

The existence of statistical literacy ability is influenced by many factors, one of which is the initial statistical ability. Initial statistical ability is the ability that students have before participating in the 
statistics learning given so that the initial statistical ability affects students in statistical literacy abilities. Besides, Gal (2002) also states that statistical literacy is influenced by cognitive and dispositional components. The cognitive components include literacy skills, statistical knowledge, mathematical knowledge, context knowledge, and critical questions, while the dispositional components include belief or behavior and the critical level of statistical data. From the cognitive component, basic knowledge of statistics affects students' statistical literacy. In addition, there is research that students with different initial knowledge also have differences in literacy abilities (Pamungkas \& Khaerunnisa, 2020).

According to the study of Watson \& Callingham (2003), there are six levels of statistical literacy hierarchy, including idiosyncratic understanding (level 1), informal understanding (level 2), inconsistent understanding (level 3), consistent non-critical understanding (level 4), critical understanding (level 5), and critical-mathematical understanding (level 6). The hierarchical levels of statistical literacy explain the level of understanding of students' arguments in reading and interpreting data through critical thinking. Çatman Aksoy \& Işıksal Bostan's research (2020) states that the level of statistical literacy of junior high school students can be identified as level 3 or level 4 in the average conceptual framework and level 1 or level 2 on the concept of variation. However, from the relevant research, it cannot be generalized to high school students. because it is different in knowledge and experience in everyday life.

It is important to state that a researcher should consider to select subjects with the same gender in conducting research, in order to minimize bias. This is supported by the results of
Risqi's study (2020) that there are differences in statistical literacy abilities in subjects with different genders.

Based on the background that has been presented, the aims of this study is to describe the statistical literacy skills of high school students in solving contextual problems in terms of their initial statistical abilities. That it is important to do this research.

\section{Research Method}

This study is descriptive-qualitative in nature. This is in accordance with the research definition by Siswono (2019) which states that qualitative research procedures are research that produces descriptive data such as speech, writing and observable behavior.

In this study, as the main instrument is the researcher herself, while the supporting instruments used include the statistical preliminary ability test (TKAS), the statistical literacy test, and interview guidelines. The subjects of this study consisted of 31 students of Grade XII at SMA Negeri 2 Nganjuk, majoring in Science, in the odd semester of the 2020/2021 academic year.

The determination of the subject was obtained by providing an initial ability statistics test (TKAS). Then, the result of this initial statistical ability test was categorized, and in turn the researcher selected one female student for each category (low, average, and high) initial statistical ability. Furthermore, the three research subjects were given a Statistical Literacy Test (TLS) to solve contextual problems which were used to determine the statistical literacy abilities of high school students. After that, the three subjects were interviewed. As for the purpose of the interview is to obtain more complete information regarding the students' statistical literacy abilities.

To further analyze the data, the results of statistical literacy tests were 
coded as follows. The Q1 test for questions with Tier 1 indicators in understanding, reading charts and explaining the information; The Q2 test for questions with Tier 2 indicators in describing data, analyzing, interpreting, interpreting and making conclusions based on the data; and the Q3 test for questions with Tier 3 indicators to present data in other forms, for example tables and making predictions, evaluating, and the explanation. Then, each answer of subject would be categorized by hierarchy of statistical literacy of Watson and Callingham (2003).

\section{Result and Discussion}

Data and Analysis of Statistical Literacy Tests for Students with High Statistical Initial Ability in Solving Contextual Problems.

a. Statistical literacy of high statistical initial ability subjects in Tier 1 .

\begin{tabular}{|c|c|}
\hline $\begin{array}{l}\text { "Kelompok umur dengan persentase meringgal paling ingai } \\
\text { adalah lebih dari } 60 \text { tahun. } \\
\text { Nelompok umur dengan persentase meninggal paling ren- } \\
\text { dah adalah antara 0-5 tahun } \\
\rightarrow \text { Data tersebut pasti dapat berubah untuk hari-hari } \\
\text { berikutnya karena pasti akan ada pasien sembuh, } \\
\text { meningagl atau malah positif covid-19. }\end{array}$ & KSA1 \\
\hline \begin{tabular}{l|l} 
& Daftar Kelompok Umur \\
\end{tabular} & \\
\hline $\begin{array}{ll}\text { Kelompok menderita positif covid-19 } & 1.31-450 \\
\text { dengan jumlah terbesar (Kelompok } & 2.19-30 \rightarrow 24,7 \% \\
\text { A) } & 3.46-59 \rightarrow 23,2 \%\end{array}$ & KSA3 \\
\hline $\begin{array}{lll}\text { Kelompok menderita positif covid-19 } & 1.0-5 \rightarrow 2 \rightarrow, 6 \% \\
2.6-18 & \rightarrow 6,6 \%\end{array}$ & \\
\hline
\end{tabular}

dengan jumlah terkecil (Kelompok B) $3 . \geqslant 60 \rightarrow 10.3$

Figure 1. Q1 Solution of GMB

From Figure 1, it can be seen that GMB subject is categorized as level 5 (critical) on the Tier 1 indicator Q1 (Q1a and Q1b) questions, including GMB's answer on KSA1 (reading data presented in graphical form). In other words, GMB is able to interpret existing symbols and numbers, as well as distinguish the highest and lowest percentage of deaths correctly. For KSA2 (explaining the data information as a whole), she can explain that the data can change in the next day.
It means that she is able to explain the differences in each histogram, is able to read fluctuations in histogram data, use the correct terminology, accompanied by arguments which is easy to understand.

For Q2, GMB questioned on KSA3 (grouping data correctly), that is, GMB is able to read the percentage data in each histogram, then use the statistical concept in grouping the data.

b. Statistical literacy of high statistical initial ability subjects in Tier 2 .

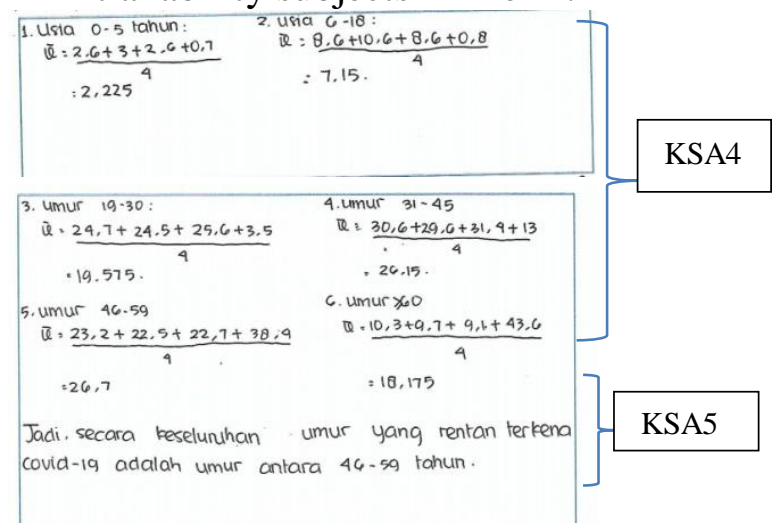

Figure2. Q2 Solution of GMB

From Figure 7, it can be seen that GMB can be categorized as at level 6 (mathematics critical) on Tier 2 including KSA4 (analyzing using statistical terminology), i.e. GMB can calculate the mean in each age group, so it indicates that GMB is able to use statistical terminology to answer questions.

For KSA5 (interpret and conclude), GMB can interpret the results of the calculations, and then conclude with clear and logical reasons.

c. Statistical literacy of high statistical initial ability subjects in Tier 3 . 


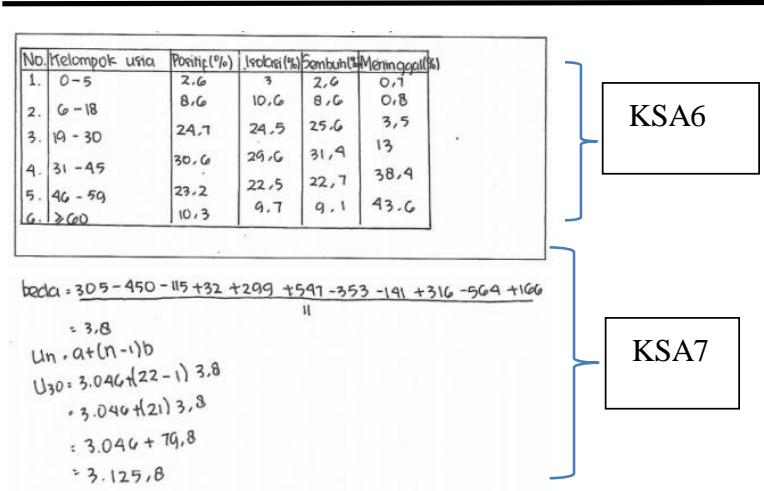

Figure 3. Q3 Solution of GMB

From Figure 3, it can be found that CBM can be classified at level 5 (critical) on the Tier 3 indicator, the data is on KSA6 (presenting data in other forms), i.e. CBM can change the form of graphical data into tables with rows as age groups and columns as percentages the number of people who were positive, isolated, cured and died in a concise and understandable manner; on KSA7 (making predictions), that is, GMB calculates the difference in the number of positive covids from the previous day then performs an average calculation to determine the difference then uses the arithmetic formula to solve it.

Based on the results of the research and interview snippets that have been carried out, in solving contextual problems related to statistical literacy, the first step taken by student with high initial statistical ability is reading the graph starting from the title, followed by explaining each histogram and its percentage, then solving the problem using statistical terminology, namely, mean, median, mode, range, correctly and precisely. Thereafter, she strengthens her argument with real context, proposes proportional reasoning, as awell as understands various possibilities. The subject is also able to analyze and interpret data clearly, understand data fluctuations, interpret data qualitatively and critically, then make appropriate and easy to understand conclusions.

In addition, the subject is able to present data information in another form practically, and explain one by one the data in each group. Besides, the subject is able to predict and evaluate the data based on the knowledge that has been obtained, but she is not sure that these predictions can be justified.

\section{Data and Analysis of Statistical} Literacy Tests for Students with Medium Statistical Initial Ability in Solving Contextual Problems.

a. Statistical Literacy of Subjects Initial Statistics Ability Medium in Tier 1

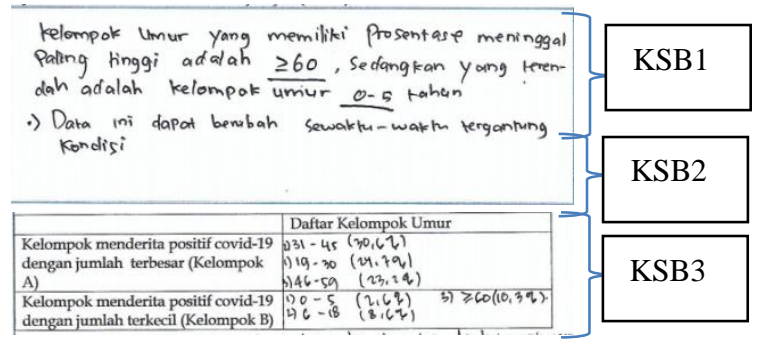

Figure 4. Q1 Solution of APA

From Figure 4, it can be found that APA is categorized as at level 3, because she is inconsistent in Tier 1, including in KSB1 (reading data presented in graphical form). However, APA can interpret existing symbols and numbers, and she can distinguish the highest and the lowest percentage of deaths correctly. For KSB2 (explaining information), APA explains that data can change, without being accompanied by clear reasons.

For KSB3 (grouping data), APA can classify percentage data in each group correctly, but the argument for using statistical terminology is still not quite right. 
b. Statistical Literacy of the Subject Initial Ability of Medium Statistics in Tier 2

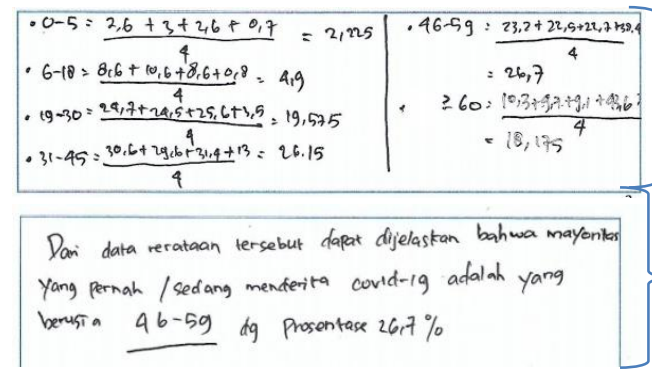

Figure 5. Q1 Solution of APA

From Figure 5, it can be seen that APA can be classified at level 5, for the reasons that she is critical in Tier 2 including the KSB4 (analyzing using statistical terminology). She can also analyze the mean in each age group. It means that she can use statistical terminology to answer questions.

For KSB5 (interpret and conclude), APA is able to interpret the results of calculations, and to draw conclusion with clear and logical reasons.

c. Statistical literacy of the subject with average initial statistical ability in Tier 3

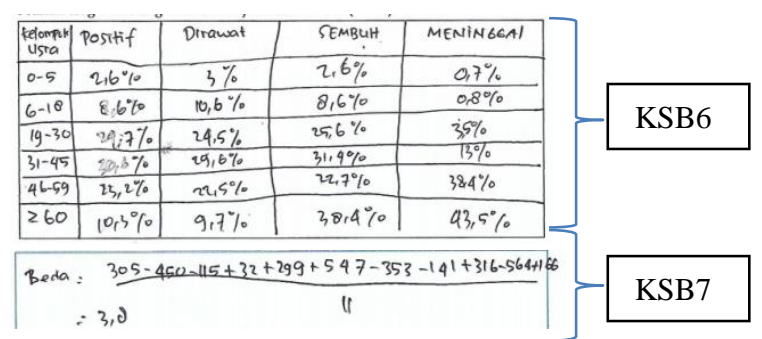

Figure 6. Q1 Solution of APA

From Figure 6, it can be found that APA can be classified as at level 3, because she is inconsistent on the Tier 3 indicator, for example, in KSB6 (presenting data in other forms), that is, she can change the form of graphical data into a table with the rows as age groups, and the columns as a summary percentage. It is also easy to understand.

For KSB7 (making predictions), APA only calculates the difference in the number of positive people with Covid to determine the mean with an unclear and unpredictable purpose.
KSB5
Statistical Literacy Analysis of High School Students in Solving Contextual Problems in terms of Average Initial Statistics Ability

Considering the results of the data analysis and interview snippets that have been carried out, in solving contextual problems related to statistical literacy, the first step taken by student with medium (average) initial statistical ability is reading the graph starting from the title, then explaining each histogram and its percentage, followed by solving the problem using statistical terminology. (average, median, mode, range). However, what she did is still not quite right, so that the solution she found is not correct. Afterwards, she strengthens her argument with real context, and she sometimes answered questions only by using intuition or estimation. Her proportional reasoning is not quite right, as she did not understand the various possibilities. This subject is able to analyze and interpret data clearly, understand data fluctuations, but in terms of interpretation, it cannot yet be understood. However, she is able to draw conclusions based on calculations.

In addition, this subject is able to present data information into another form practically and explain one by one the data in each group, before she hesitated to predict the probability by 
calculating the mean, eventhough she did not find the final answer.

\section{Data and Analysis of Statistical Literacy}

Test for Students with Low Initial Statistics Ability Solving Contextual

\section{Problems}

a. Statistical Literacy of Subjects Low

Initial Statistics Ability in Tier 1

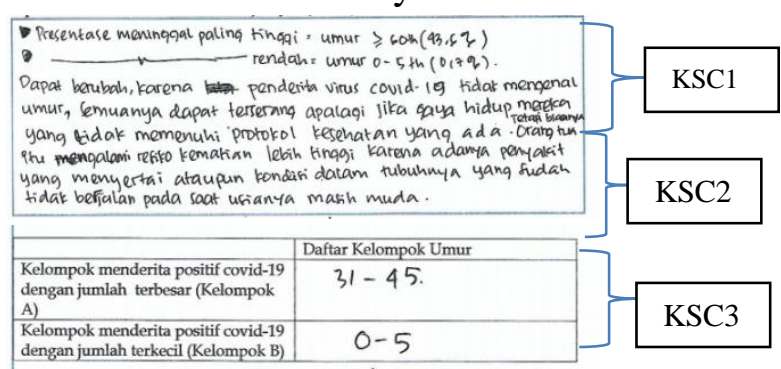

Figure 7. Q1 Solution of MDS

From Figure 7, it can be seen that MDS is classified at level 3, since she is inconsistent in Tier 1, including at KSC1 (reading data presented in graphical form), she can interpret existing symbols and numbers, and she can distinguish the highest and lowest percentage of deaths correct. For KSC2 (explaining information), MDS is able to explain that data can change along with reasons related to the context; in KSC3 (grouping data), MDS only wrote one highest age group and one lowest age group, so that the answer was incomplete.

b. Statistical literacy of subjects, low initial statistical ability in Tier 2

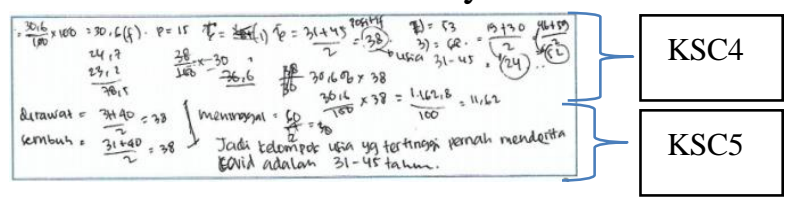

Figure 8. Q1 Solution of MDS

From Figure 8, it can be seen that MDS can be included at level 1 idiosyncratic in Tier 2, because for KSC4 (analyzed using statistical terminology), she only analyzed the mean of two specific age groups based on intuition; in KSC5 (interpreting and concluding), MDS was unable to interpret the data completely, so that her written conclusions were incorrect.

c. Low Statistics Initial Capability Statistics Literacy in Tier 3

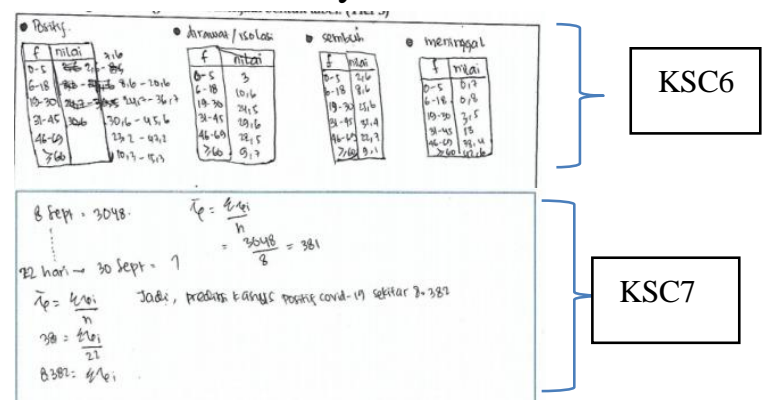

Figure 9. Q1 Solution of MDS

From Figure 9, it can be seen that MDS can be included at level 3, because she is inconsistent on the Tier 3 indicators. For KSC6 (presenting data in other forms), MDS can change the form of graphical data into four different tables, but there is an error in the first table. She did not make the table briefly.

For KSC7 (making predictions), MDS calculated the mean without giving a reason that is easy to understand. It is implied that her objectives are not clear and cannot be used to predict.

\section{Statistical Literacy Analysis of High School Students in Solving Contextual Problems in terms of Low Initial Statistics Ability}

Based on the results of the research and interview snippets that have been carried out, in solving contextual problems related to statistical literacy, the first step taken by students with low initial statistical abilities is reading the 
graph starting from the title, then explaining each histogram and its percentage, sometimes using the correct terminology but produce a wrong answer. She sometimes can answer correctly, but her arguments are only based on intuition. She did not understand the concept of probability, thet in turn producing a wrong answer.

This subject is less able to analyze and interpret data clearly, to understand data fluctuations, but she mainly used her intuition in answering question. She also draw conclusions based on calculations.

In addition, the subject is able to present data information in another form, but it is impractical, and explains one by one of the data in each group. Finally, it can be said that the subject cannot predict and evaluate in a logical way.

\section{Discussion}

Considering the results of data analysis, the following will present a discussion of the statistical literacy profiles of high school students in solving contextual problems with high, medium and low initial statistical abilities. The discussion is based on Watson's (2000) statistical literacy hierarchy, covering 6 levels including idiosyncratic (level 1), informal (level 2), inconsistent (level 3), consistent non-critical (level 4), critical (level 5), and mathematics critical (level 6).

During the completion of the statistical literacy test that has been given, students with high initial statistical abilities are at level 5 to 6 (CriticalMathematics Critical) including in Tier 1 reading ability (differences in histogram colors, symbols, numbers, percentages and descriptions), explaining information graph correctly, where at the time of the interview the students use their arguments accompanied by statistical terminology correctly and are able to involve reasoning that is proportional to the real context.

In Tier 2 students with high initial abilities are able to analyze data using statistical concepts and the concept of opportunity, including (1) using the mean concept in analyzing and determining conclusions among the age group percentage data, (2) using the mode to determine the highest score, (3) using the median concept to group data correctly, (4) using the concept of probability correctly, (5) able to interpret each histogram difference and data fluctuation, (6) interpreting by revealing the overall information from the data. In addition, students also perform simple calculations that are used to strengthen explanations of statistical information and draw conclusions.

In Tier 3, the student with high initial skills is able to present data in other forms practically and informatively, and she uses tables with easy-tounderstand columns and rows. However, this students is hesitant in predicting something using the provided data, but in the end, she can complete it well according to their limited knowledge. This is in accordance with the opinion of Hafiyusholeh (2017) that female students with high mathematical abilities in reading data start by paying attention to the graphic/ diagram titles and information on each given axis, students dig up direct information from what is written explicitly based on the graph, 
interpreting and concluding the data, students pay attention to the general pattern of data fluctuation and use general data trends to predict the possibility of future data and determine the value of data increase or decrease based on their average value.

In addition, this study is in line with the one conducted by Cahyawati \& Prabawanto (2020), that the student with high initial knowledge can successfully provide approximate answers by using a solution process that is relevant to the problem.

During the completion of the statistical literacy test that has been given, students with average (medium) initial statistical ability is at level 3 to level 5 (Inconsistent-Critical). In Tier 1, reading data, (differences in histogram colors, symbols, numbers, percentages and descriptions), explaining information graph correctly, where at the time of interviewing students use arguments accompanied by statistical terminology but not quite right, sometimes using intuition, so that the answer is correct but the reason is not right.

In Tier 2, the student with average initial ability is able to analyze data using statistical concepts, and probability concepts, for example, she uses the concept of averaging in analyzing and determining conclusions between the highest group percentage data accurately and clearly, using mode to determine the highest score, when grouping data, students use the wrong argument, namely the concept of mode, use the concept of probability, but the wrong answer is able to interpret each histogram difference and data fluctuation, interpret it by revealing the overall information from the data. In addition, students also do simple calculations even though something is wrong which is used to strengthen the explanation of wrong statistical information and draw conclusions. In Tier 3 students with medium initial abilities are able to present data in other forms practically and informatively, students use tables with easy-tounderstand columns and rows. Students hesitate in predicting something using data so she do not arrive at the final answer. This is in line with Cahyawati \& Prabawanto's (2020) research that students with medium statistical abilities can provide approximate answers but have not been able to explain the solutions given.

During the completion of the statistical literacy test that has been given, students with low initial statistical abilities are at level 1 to level 3 (Idiosyncratic-Consistent Noncritical) including in Tier 1 reading data (differences in histogram color, symbols, numbers, percentages and descriptions) Correct graphic information, where at the time of the interview students use their arguments accompanied by statistical terminology but not quite right, often use intuition so that the answer is correct but the reason is not right. In Tier 2 students with low statistical skills in analyzing data use statistical concepts and the concept of probability, among which students use the concept of mean in analyzing and determining conclusions among the highest percentage of group data but based on interview arguments students only choose certain data groups through intuition or estimation so that the 
calculation is still not precise, using mode to determine the highest value but when classifying the wrong subject data and the wrong interview argument, namely using the mode concept, using the concept of probability but in general students do not understand the concept correctly so that the answer cannot be accounted for, able to interpret any differences histogram and data fluctuation, interpret by revealing information from the data. In Tier 3, the student with low initial statistical abilities are able to present data in other forms but impractical, students use 4 tables with easy-to-understand columns and rows. Students hesitate in predicting something using data, using the concept of mean but the arguments expressed are not clear. This is in accordance with the research of Cahyawati \& Prabawanto (2020) that students with low initial abilities have not been able to determine the size of concentration and provide conclusions given that are not clear enough, are still limited. In addition, this is in accordance with the research of Setianingsih \& Rahmah (2020) that students with low initial abilities also have low statistical reasoning at level 1 to level 2. Students determine mode values with wrong concepts, unable to interpret data and arguments that are incorrect. The findings of this study were students with low initial abilities were able to read data correctly and explain the data clearly. However, students often use intuition in solving contextual problems while using statistical terminology but it is wrong and in general the concept of statistics is still not understood.

\section{Conclusion}

There are differences in solving statistical literacy problems with contextual problems of subjects with high, average, or low initial statistical abilities. Then the conclusions can be obtained as follows.

1. Statistical literacy skills in solving contextual problems with high initial statistical abilities are categorized at level 5-6 (Critical-Mathematics Critical). In Tier 1, the students generally can understand how to read data and explain data correctly. Ability in Tier 2, analyze, interpret, interpret and make conclusions correctly accompanied by precise statistical terminology. In Tier 3, students are able to present data into other forms practically, and be able to make predictions.

2. Statistical literacy skills in solving contextual problems with average/ medium statistical initial abilities are categorized at level 3 to level 5 (Inconsistent-Critical). In Tier 1, this student in general is able to read data and explain data correctly. Whereas in Tier 2, she is able to analyze, interpret, as well as interpret-and-draw conclusions using terminology that is sometimes correct or incorrect, and she only uses intuition. Furthermore, in Tier 3, this student is able to present data into other forms practically, but she is not able to make predictions.

3. Statistical literacy skills in solving contextual problems for student with low initial statistical ability are categorized at level 1 to level 3 (Idiosyncratic-Consistent Noncritical). In Tier 1, in general, the student can understand how to read data and 
explain data correctly. While in Tier 2, she is able to analyze, interpret-anddraw conclusions, eventhough sometimes incorrect and inaccurate in using statistical terminology. She is also only use intuition. In Tier 3, the student is able to present data in other forms, but still impractical and unable to make predictions.

\section{Suggestion}

1. For further research, it is necessary to add another control variable, namely the level of student reasoning. Because statistical literacy is influenced by the level of criticality of students, different students will also affect statistical literacy skills. This is in accordance with the research of Setianingsih \& Rahmah (2020) that solving statistical problems is influenced by the level of statistical reasoning which states that students who have low initial ability also have low statistical reasoning abilities. Furthermore, it is better to look at other factors such as male subjects. This is in line with Risqi's (2020) research that there are differences in statistical literacy abilities with different genders.

2. Students with medium and low initial statistical abilities, find it difficult to analyze, interpret, and make conclusions based on statistical terminology, so she need special treatment from the teacher, especially the context given to improve statistical literacy skills. In terms of presenting student data with low initial statistical abilities, it requires special treatment from the teacher regarding various forms of data. In terms of predicting data, students with medium and low initial statistical abilities need special treatment from the teacher, especially in the concept of statistics and opportunities.

\section{References}

Abdullah, A.A. (2017). Meningkatkan Kemampuan Berpikir Kritis Melalui Pembelajaran Statistika Berbasis Pendidikan Politik di Lingkungan Sekolah. Jurnal Gantang, II.

Cahyawati, D., \& Prabawanto, S. (2020). Eksplorasi Kemampuan Awal Statistis Mahasiswa dalam Topik Statistika Deskriptif. 2682, 201-212.

Carver, R., College, S., Everson, M., \& Ohio, T. (2016). Guidelines for Assessment and Instruction Guidelines for Assessment and Instruction Guidelines for Assessment and Instruction Guidelines for Assessment and Instruction in Statistics Education (GAISE) in Statistics Education. July, $\quad 1-141$. http://www.amstat.org/education/gai se.

Çatman Aksoy, E., \& Işıksal Bostan, M. (2020). Seventh Graders' Statistical Literacy: An Investigation on Bar and Line Graphs. International Journal of Science and Mathematics Education.

https://doi.org/10.1007/s10763-020$10052-2$

Eka, P., Nurjannah, I., \& Sayoga, R. (2020). Improve the Mathematical Literacy Ability of Junior High School Students Through A. 3 (1), 43-48.

Gal, I. (2002). Adults' Statistical Literacy: Meanings, Components, Responsibilities. International Statistical Review, 70 (1), 1-25. https://doi.org/10.1111/j.17515823.2002.tb00336.x 
Gal, I. (2019). Understanding statistical literacy: About knowledge of contexts and models. Actas Del Tercer Congreso Internacional Virtual de Educación Estadística. http://digibug.ugr.es/bitstream/handl e/10481/55029/gal.pdf? sequence $=1$ \&isAllowed $=\mathrm{y}$

Hafiyusholeh, M., Budayasa, K., \& Siswono, T. Y. E. (2017). Literasi Statistik: Siswa SMA dalam Membaca, Menafsirkan, dan Menyimpulkan Data. Prosiding SI MaNIs (Seminar Nasional Integrasi Matematika dan Nilai Islami), 1(1), 79-85.

Mardliyah, A. A. (2018). Budaya Literasi sebagai Upaya Peningkatan Keterampilan Berpikir Kritis di Era Industri Revolusi 4.0. Jurnal Pendidikan, 2, 12-21.

NCTM. (1989). Curriculum and evaluation standard for school mathematics. the National Council of Teachers of Mathematics, Inc.

Pamungkas, A. S., \& Khaerunnisa, E. (2020). The analysis of student's statistical literacy based on prior knowledge and mathematical self esteem. Journal for the Mathematics Education and Teaching Practices, 1(1), 43-51.

Pendidikan, K., \& Jakarta, K. (2017). Panduan Gerakan Literasi Nasional.

Permendikbud. (2016). Permendikbud Nomor 24 Tentang Kompetensi Inti dan Kompetensi Dasar Tahun 2016. Kemendikbud.

Risqi, E.N. (2020). How is Statistical Literacy of Secondary School Based on Gender Differences? (p. no. 01 53-67). JRPIPM (Jurnal Riset Pendidikan dan Inovasi Pembelajaran Matematika). journal.unesa.ac.id/index.php/jrpipm Setianingsih, R., \& Rahmah, D. A. (2020). Statistical reasoning levels of high school students in solving statistics related problems. Journal of Physics: Conference Series, 1569(4).

https://doi.org/10.1088/1742-

6596/1569/4/042064

Sharma, S. (2017). Definitions and models of statistical literacy: a literature review. Open Review of Educational Research, 4(1), 118133.

https://doi.org/10.1080/23265507.20 17.1354313

Siswono, T.Y.E. (2019). Paradigma Penelitian Pendidikan: Pengembangan Teori dan Aplikasi Pendidikan Matematika. Bandung: Remaja Rosdakarya.

Van Laar, E., van Deursen, A.J.A.M., van Dijk, J.A.G.M., \& de Haan, J. (2020). Determinants of 21stCentury Skills and 21st-Century Digital Skills for Workers: A Systematic Literature Review. SAGE Open, $\quad 10$ https://doi.org/10.1177/2158244019 900176

Watson, J. \& Callingham, R. (2003). Statistical literacy: A complex hierarchical construct. Statistics Education Research Journal, 2(2), 3-46.

http://www.stat.auckland.ac.nz/ iase /serj/SERJ2(2)_Watson_Callingham .pdf

Watson, J.M., \& Moritz, J.B. (2000). Development of understanding of sampling for statistical literacy. Journal of Mathematical Behavior, 19(1), 109-136. https://doi.org/10.1016/S07323123(00)00039-0

Yuniawatika, Y. (2018). Statistical Literacy and Its Urgency for Students. 269(CoEMA), 170-173. https://doi.org/10.2991/coema18.2018 .41 